\title{
KELUARGA BEDA AGAMA DALAM MASYARAKAT JAWA PERKOTAAN Studi Kasus di Sinduadi Mlati Sleman Yogyakarta
}

\author{
Oleh: Nawari Ismail*
}

\section{Abstract.}

This research purposes to explain the religiosity of couple both before and after marriage; to describe function of culture in the social integration among the couple which has different religion, before and after marriage; and to state the socialization of value of parent to their children. This research uses ethnographical approach in the Javanese urban, especially in Sinduadi Mlati Sleman Yogyakarta. The research is applied in some steps; exploring data, recognizing physical sphere, the research conducting, and writing report. The research revealed some point as follow: (I) Most couple have highly religious and the other are sufficient. (2) Religion, as cultural system, is very useful to integrate social factor of the couple in the religious intermarriage case that caused by values of sincreticsm of 'abangan'subculture on the one hand, and the other hand also caused by values of secularization of 'santri'subculture, so that the tolerance attitude toward others religion is increased. (3) The role of religious culture is not dominant in socializing value and applying inheritance law.

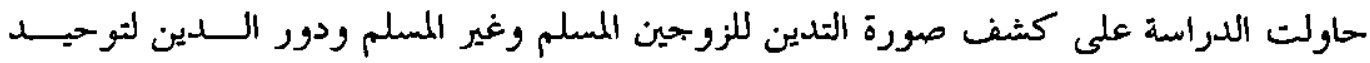

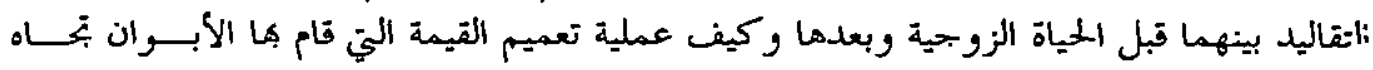

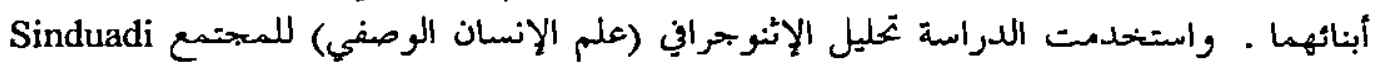

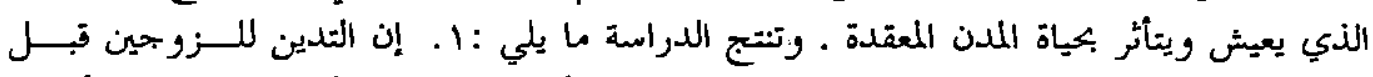

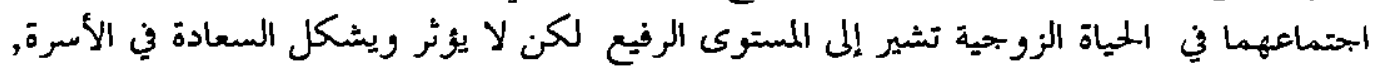

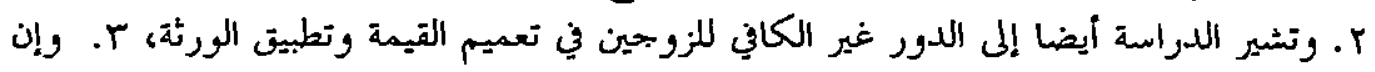

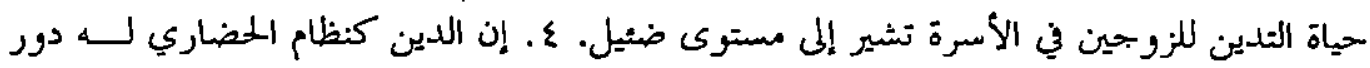

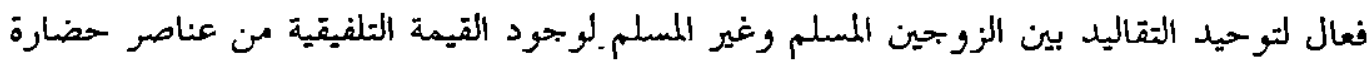
abangan

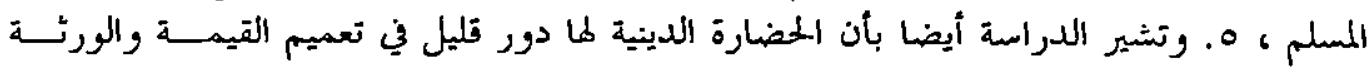

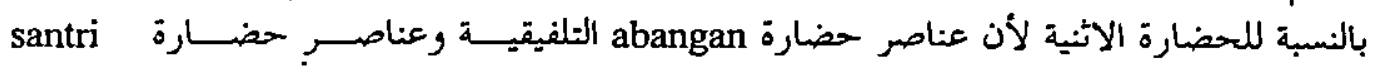

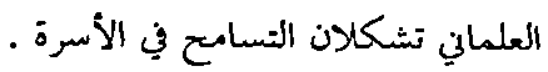

Kata Kunci: Keluarga, Keberagamaan, Perkawinan Beda Agama

'Dosen Universitas Muhammadiyah Yogyakarta 


\section{A. Pendahuluan}

D ada dataran realitas menunjukkan masyarakat Indonesia bersifat pluralis, baik dari segi agama maupun suku. Karena itu adanya toleransi dan pengakuan terhadap pluralisme akan menghindarkan kelompok-kelompok masyarakat bersikap eksklusif, sehingga memudahkan terjadinya integrasi. Apalagi memasuki millenium ketiga, ketika perubahan sosial-budaya terus berlanjut dengan akselarasi yang lebih cepat, seiring dengan proses globalisasi yang menjadikan masyarakat berada dalam satu jaringan desa-dunia. Dunia yang seperti desa menjadi tempat bertemunya berbagai aspek sosial-budaya, ${ }^{1}$ sehingga memudarkan sekat-sekat geografis antarnegara dan berimplikasi juga kepada meretasnya sekat-sekat sosial, keagamaan, etnisitas dan keluarga.

Keluarga sebagai institusi sosial terkecil mempunyai peran yang sangat penting dalam proses alih kebudayaan antargenerasi, termasuk dalam pengalihan nilai-nilai moral, toleransi dan pengakuan terhadap perbedaan. Keluarga juga dapat berposisi sebagai struktur mediasi penting dalam proses sosialisasi nilai-nilai dan ide-ide dari institusi riegara (pemerintah) atau masyarakat kepada individu (anggota keluarga).

Dalam arus perubahan sosial-budaya tersebut keluarga moderen juga ditandai dengan pluralisme latar-belakang sosial-budaya anggota keluarga, misalnya perbedaan agama. Keluarga beda agama walaupun belum ada data resmi dari hasil sensus, temyata jumlahnya cukup banyak terutama di perkotaan. Sebagai contoh Ikatan Keluarga Lintas Agama dan Suku Indonesia (IKLAS-Indonesia), menurut ketuanya, Ir. Sigit Susilo, ${ }^{2}$ telah mempunyai anggota sebanyak 200 Kepala Keluarga (KK) khusus sebagian yang berada di Bali, Yogyakarta dan Jakarta.

Keluarga beda agama, sebagaimana institusi keluarga pada umumnya, merupakan pusat pembinaan kebudayaan awal individu, baik kebudayaan yang bersumber dari tradisi suku (kebudayaan-suku) maupun kebudayaan yang bersumber dari agama (kebudayaan-agama) atau kebudayaan campuran. Sebagai suatu sistem simbol yang mempunyai makna bagi penganut dan pendukungnya, agama tentu akan berpengaruh terhadap sikap, perilaku dan pola hidup suami-isteri dan anggota keluarga. Sebab seperti kerangka pikir sibernika Parsons bahwa, sistem budaya berpengaruh kepada sistem sosial. ${ }^{3} \mathrm{Hal}$ ini mengandaikan bahwa, agama sebagai sebuah kebudayaan, dalam intensitas seberapapun dapat menjadi faktor independen dalam hubungannya dengan struktur dan fungsi keluarga beda agama.

Di sisi lain dalam keluarga beda agama dimungkinkan terjadinya tarik-menarik kekuatan antarkebudayaan yang dilakukan orang tua yang berbeda agama terhadap

'James Beckford dan Thomas S. Kuhn, 1991, The Changing Face of Religion, London: Sage, hal.11.

${ }^{2}$ Kedaulatan Rakyat, 24 Januari 2000.

${ }^{3}$ Lihat Parsudi Suparlan, 1982, Pengetahuan Budaya, Ilmu-ilmu Sosial dan Pengkajian Masalah-masalah Agama, Jakarta: Proyek Penelitian Keagamaan Balitbang Depag RI, hal. 70. 
anak-anaknya. Selain itu keberadaan keluarga beda agama sering menimbulkan kontroversi di kalangan masyarakat dan sering dilihat hanya dari sisi yuridis-formalnya.

Inti penelitian ini berusaha mengkaji hubungan kebudayaan (suku dan agama) dengan struktur sosial dalam keluarga beda agama. Adapun fokusnya adalah: (a) adatidaknya pengaruh perkawinan beda agama terhadap kualitas keberagamaan masingmasing pihak; (b) fungsi kebudayaan-agama dalam pengintegrasian sosial antara suamiisteri yang berbeda agama, baik ketika terjadinya perkawinan maupun setelah suami isteri berumah-tangga; (c) proses sosialisasi nilai terhadap anak yang dilakukan suamiisteri yang berbeda agama, termasuk mengenai ada-tidaknya dominasi antarkebudayaan, dan faktor penyebab terjadinya dominasi

Dalam menjawab masalah tersebut dilakukan pendekatan struktural fungsional. Adapun asumsinya adalah hubungan antara sistem budaya (agama) dengan sistem sosial (struktur dalam keluarga) merupakan hubungan timbal-balik. Agama sebagai sistem budaya mempengaruhi dan dipengaruhi realitas.

\section{B. Tinjauan Pustaka}

\section{Penelitian Terdahulu}

Institusi keluarga sudah lama menjadi sasaran penelitian. Dalam perspektif fungsionalisme-struktural, penelitian tentang keluarga difokuskan kepada struktur dan fungsinya. Di Indonesia penelitian keluarga dengan pendekatan fungsionalisme tersebut misalnya penelitian yang dilakukan Hildred Geertz (1985). Geertz menggunakan pendekatan etnografi khusus mengkaji keluarga Jawa dengan memfokuskan kepada struktur, peran keluarga dan sosialisasi nilai tradisi dalam keluarga Jawa.

Untuk penelitian yang memfokuskan perhatian terhadap keluarga beda agama sebenarnya sudah ada yang meneliti. Bahr (1982) melakukan penelitian di keluarge beda agama ( religious intermarriage) di Amerika, demikian juga dengan Nelsen (1990) diAustralia. Kedua peneliti tersebut menyoroti aspek sosialisasi nilai keagamaan dalam keluarga beda agama dan peran yang dimainkan suami-isteri dalam sosialisasi nilai keagaamaan tersebut.

Di Indonesia sendiri sudah ada penelitian tentang keluarga beda agama, seperti yang diteliti oleh Aini (1997/1998) dan Wiludjeng(1991).Aini melakukan penelitian data sekunder (dari hasil sensus SUSENAS, 1980) khusus Daerah Istimewa Yogyakarta tentang keluarga yang beragama Islam, Kristen dan Katolik. Aspek yang dikaji adalah afiliasi agama anak dalam keluarga beda agama dan peran masing-masing suami-isteri. Sementara itu Wiludjeng khusus mengkaji pelaksanaanjanji perkawinan dari suami-isteri yangkawin dengan umat non-Katolik dan pengaruhnya terhadap proses pengafilisian anak.

2. Kebudayaan, Agama, dan Interaksi Sosial

Kebudayaan adalah seperangkat ide atau pengetahuan yang dimiliki manusia sebagai makhluk sosial yang secara selektif digunakan untuk memahami dan 
menginterpretasikan lingkungan yang dihadapi serta dijadikan sebagai kriteria dalam bersikap, bertindak dan berinteraksi dengan orang lain. ${ }^{4}$

Kebudayaan dapat bersumber dari ajaran agama (kebudayaan-agama) dan nilainilai suku (kebudayaan-suku). Sebuah komunitas suku dan agama dapat memiliki kebudayaan khusus yang disebut dengan subkebudayaan, misalnya dalam masyarakat agama (Islam) di Jawa ada subkebudayaan abangan dan santri. Sementara dalam masyarakat suku Jawa ada subkebudayaan Jawa-pesisir dan Jawa-pedalaman.

Dalam hal hubungan antara kebudayaan dengan struktur sosial, seperti interaksi sosial, kegiatan sosialisasi nilai, dapat dilakukan melalui berbagai pendekatan, misalnya pendekatan hermeneutik, semiotik, dan pendekatan fungsionalisme-Parsons. Pendekatan fungsionalismememandang adanya hubungan timbal-balik antara kedua variabel tersebut. ${ }^{5}$

Interaksi sosial merupakan hubungan timbal balik antar individu atau antar kelompok sosial dalam masyarakat. Dalam konteks kehidupan keluarga berarti hubungan timbal balik antar anggota keluarga. Bentuk interaksi sosial antar anggota keluarga beda suku-agama dapat bersifat positif dan negatif. Bersifat positifjika ada integrasi, bersifat negatifjika terjadi pertengkaran dan bahkan perceraian antara suami dan isteri.

Dalam hal ini integrasi sosial berarti penyatuan antara laki-laki dan perempuan yang berbeda agama-suku dalam sebuah perkawinan. Kemudian setelah berada dalam suatu perkawinan mereka memelihara keharmonisan rumah tangganya. Keharmonisan merupakan tujuan utama dari setiap orang yang melakukan perkawinan. Konflik bukan tujuan namun sangat mungkin hanya dipandang sebagai proses sementara. Persoalannya mengapa terjadi integrasi di antara orang yang berbeda agama. Hal ini dapat dijelaskan dari teori modernitas yang menyatakan bahwa, masyarakat moderen cenderung bersifat toleran terhadap agama lain (Nottingham, 1983). Di Indonesia dari ketiga varian agama Jawa seperti dikemukakan Clifford Geertz (1989) nampak varian abangan sangat memperlihatkan ciri-ciri seperti masyarakat moderen yaitu adanya toleransi beragama yang tinggi (Hildred Geertz, 1985). Sikap toleransi ini yang dimungkinkan mempengaruhi berkembangnya perkawinan beda agama.

Untuk itu Hildred Geertz ${ }^{6}$ menemukan kenyataan bahwa, kategori abangan dalam masyarakat Islam Jawa, memperlihatkan ciri-ciri seperti masyarakat moderen yaitu adanya toleransi beragama yang tinggi, sehingga mempengaruhi berkembangnya perkawinan beda agama. Sementara Collins (1987), yang melakukan penelitian pada masyarakat Amerika, menemukan kenyataan bahwa, konflik (perceraian) lebih sering terjadi di kalangan keluarga beda agama dibandingkan dengan keluarga satu agama.

${ }^{4}$ Lihat Sudjangi, 1992, Kajian Agama dan Masyarakat, Jakarta: Balitbang Depag RI, hal. 84.

${ }^{5}$ Jeffrey C.Alexander dan Steven Seidman (eds.), 1990, Culture and Society, Contemporary Debates, Cambridge: Cambridge University Press, hal. 3-10.

${ }^{6}$ Hildred Geertz, 1985, Keluarga Jawa, Jakarta: Grafiti Press, hal. 3-4 
Hal senada dikemukakan oleh Elliott dan Merrill (dalam Khoiruddin, 1997) bahwa, perbedaan agama dalam keluarga merupakan sumber konflik terutama setelah anakanak lahir dan konflik akan lebih serius lagi jika suami-isteri memiliki kesadaran beragama yang tinggi. Dalam kaitannya dengan pernyataan Elliott dan Merrill ini, maka perlu meneliti mengenai keberagamaan suami-isteri.

\section{Keberagamaan}

Keberagamaan dapat juga disamakan dengan keterlibatan agama atau komitmen agama merupakan suatu konsekuensi dari penganutan agama seseorang. Konsep keberagamaan mengandung beberapa indikator, dan di antara ahli ada perbedaan. Dengan mengacu dan memadukan indikator yang diberikan oleh beberapa ahli seperti Fukuyama yang dilansir oleh Demerath, Glack dan Ringer, Larry Blackwood yang dikutip Abdullah Fajar, dan Demerath, maka dalam penelitian ini indikator konsep keberagamaan meliputi; keanggotaan formal dalam organisai agama, kehadiran atau pelaksanaan ritual agama, partisipasi dalam kegiatan keagamaan, dan upaya memperoleh pengetahuan keagamaan.

\section{Sosialisasi Nilai dan Peranan}

Sosialisasi nilai adalah proses peralihan nilai-nilai (agama dan suku) dari seorang atau kelompok kepada orang lain, dari orang tua kepada anak-anak. Ada dua jenis sosialiasi nilai kepada anak-anak yaitu sosialisasi primer (primary socialization), dan sosialisasi sekunder (secondary socialization). ${ }^{7}$ Sosialisasi primer berlangsung ketika anak pertama kali memperoleh identitasnya sebagai pribadi. Pada tahapan ini anak sebagian besar menerima sosialisasi dari orang tua. Adapun sosialisasi sekunder merupakan sosialisasi setelah anak beranjak dewasa, dalam masa ini anak menjadi anggota masyarakat yang lebih luas dan menerima nilai-nilai dari masyarakatnya.

Proses sosialisasi dalam keluarga terkandung adanya peranan-peranan yang dimainkan orang tua. Peranan adalah aspek dinamis dari status atau kegiatan yang dilakukan seseorang sesuai dengan status yang dimilikinya. Berger dan Luckman (1971) menyatakan bahwa, peranan ditentukan dan dikonstruksikan secara sosial. Artinya peranan individu atau kelompok ditentukan oleh konsep dasar perilaku atau nilai-nilai yang dijadikan pedoman dalam masyarakat. Dalam masyarakat yang menganut ideologi patriarki misalnya, peranan laki-laki dan perempuan umumnya dibedakan (Budiman, 1985). Laki-laki dikonstruksi untuk berperan di sektor publik, sedangkan perempuan mengurusi sektor domestik.

Adanya pembagian peran antara laki-laki dan perempuan (suami-isteri) tentu akan berdampak terhadap kuantitas waktu dalam pemberian sosialisasi nilai kepada anak, sehingga akan menimbulkan dominasi peranan dari suami atau isteri dalam keluarga.

${ }^{7}$ Phillip Robinson, 1989, Beberapa Perspektif Sosiologi Pendidikan, Jakarta: Rajawali Press, hal. 50 
Jika terjadi dominasi peranan dalam proses sosialisasi nilai, maka sangat dimungkinkan terjadi dominasi kebudayaan atau sub kebudayaan dalam keluarga. khususnya dalam keluarga beda agama.

Teori tentang peranan tersebut juga didukung oleh temuan beberapa penelitian. Bahr (1982) dan Nelson (1990) sama-sama menemukan bahwa pengaruh maternal secara signifikan lebih besar dan kuat daripada pengaruh paternal dalam sosialisasi nilai (agama) anak dalam keluarga beda agama. Bahkan Nelsen juga menemukan bahwa, anak perempuan cenderung kuat mengikuti agama ibu dan sebaliknya anak laki-laki cenderung ikut agama bapak. Sementara di Indonesia, Aini (1997/1998) menemukan hal yang senada yaitu pengaruh orang tua dari keluarga beda agama dalam sosialisasi nilai agama (afiliasi agama) terhadap anak ditentukan oleh jenis kelamin. Dengan kata lain, peranan sosial suami-isteri yang didasarkan atas konsep pembagian kerja secara jender dalam masyarakat patriarki, ibu lebih dominan daripada bapak dalam sosialisasi nilai agama. Berdasarkan teori dan temuan tentang peranan dalam soalisasi nilai tersebut, I saka dimungkinkan juga berlaku dalam aspek penerapan kewarisan, jika satu di antara orang tua tersebut meninggal dunia.

Dalam kaitan ini perlu dipertimbangkan determinasi sosial budaya suami-isteri, misalnya dari segi latar belakang lapisan sosialnya, dan keberagamaan serta tingkat keketatan ajaran (ortodoksi) agama dalam melihat perkawinan beda agama. Dalam kontek ini Wiludjeng (1991) menemukan bahwa pihak (suami-isteri) Katolik dan Islam (yang dianggap lebih ortodok daripada Kristen) lebih kuat dalam mengkatolikkan dan mengislamkan anak-anaknya. Kuatnya pengaruh pihak suami-isteri Katolikkarena mereka harus melakukan janji di dan oleh gereja yang disebut dengan antinuptialagreement, sebuah perjanjian yang mengharuskan mengkatolikkan pasangan dan anaknya. Hal ini sejalan dengan temuan Nelsen (1990) bahwa, tingkat ortodoksi ajaran agama berhubungan erat dengan penganutan agama anak dalam keluarga beda agama.

\section{Manfaat Penelitian}

Penelitian ini bermanfaat dalam pengembangan wawasan mengenai sosiologi keluarga. Kajian ini belum banyak dilakukan di Indonesia, khususnya dalam kajian hubungan antarumat beragama. Karena itu hasil penelitian ini dapat dijadikan sebagai acuan dalam pembinaan dan pengembangan kebudayaan nasional, khususnya dalam pembinaan keluarga sejahtera manuju masyarakat madani. Apalagi di tengah-tengah berkembangnya konflik bernuansa agama. Hasil penelitian ini juga bermanfaat dalam memberikan wawasan dan pemahaman yang baik dalam hubungan antaragama di Indonesia. Dengan demikian hasil penelitian ini bermanfaat dalam pengambilan kebijakan dalam hal perkawinan dan model pembinaan keagamaan pada keluarga beda agama pada masa-masa yang akan datang. 


\section{Metode Penelitian}

Penelitian ini menggunakan pendekatan etnografi dengan model berpikir secara holistik maksudnya penelitian yang berusaha mencari uraian menyeluruh mengenai gejalagejala yang berkaitan dengan keluarga beda agama. Setiap gejala diperlakukan sebagai unsur-unsur yang satu dengan lainnya saling terkait.

Penelitian dilakukan di lokasi yang banyak terjadi perkawinan beda agama di masyarakat yang lebih bersifat perkotaan yaitu di Kelurahan Sinduadi Kecamatan Mlati Sleman Propinsi Daerah Istimewa Yogyakarta. Lokasi penelitian dipusatkan terutama di Gemawang, Sendowo dan Karangjati, dan Pogung.

Penelitian dilakukan dalam beberapa tahap. Pertama, penelusuran data monografi dan Kartu Keluarga di Kantor Kecamatan Mlati dan Kantor Kelurahan Sinduadi. Sementara di Kantor Utusan Agama Mlati peneliti memperoleh data tentang tugas masingmasing, proses administrasi perkawinan, dan kebijakan yang diambil ketika ada calon pasangan kawin beda agama. Kedua, pengenalan lingkungan fisik. Ketiga, penelitian lapangan yang sebenarnya, termasuk penyebaran angket. Ketiga tahapan tersebut pertama dilakukan mulai bulan awal Juli sampai akhir September 2002. Keempat, penulisan laporan.

Pengumpulan data dilakukan melalui wawancara mendalam, observasi-partisipan, angket, dan dokumenter. Wawancara mendalam berfungsi dalam dua hal yaitu:(1) sebagai pelengkap atau tindak-lanjut dari observasi partisipan, karena ada data yang tidak dapat diperoleh hanya melalui observasi partisipan atau untuk memperjelas data yang sudah diperoleh melalui angket, misalnya data tentang mengapa suami-isteri melakukan tindakan sosial tertentu, atau hukum kewarisan yang akan diterapkan (2) wawancara mendalam mandiri/utama, misalnya faktor-faktor penyebab integrasi sosial-budaya. Observas: partisipan dilakukan antara lain untuk mengetahui proses sosialisasi nilai dalam keluarga. Sementara angket digunakan untuk mengungkap data tentang keberagamaan dan hukum kewarisan yang akan ditetapkan. Informan yang diwawancarai selain informan kunci yang berbeda agama dan suami-isteri yang berbeda agama, juga pejabat pemerintah tingkat dusun, kelurahan dan kecamatan, termasuk pejabat Kantor Urusan Agama. Pengamatan dilakukan pada banyak peristiwa dan tempat seperti empat keluarga beda agama, dan kondisi geografis.

Analisis data dilakukan, seperti dikemukakan Bogdan, dalam dua tahap yaitu ketika di dalam proses penelitian di lapangan dan analisis setelah penelitian di lapangan. ${ }^{8}$ Pertama, analisis ketika di lapangan meliputi berbagai langkah, pertama data yang diperoleh ditulis dalam catatan saku yang kemudian ditulis ulang ke dalam buku catatan

${ }^{8}$ Noeng Muhadjir, 1989, Metodologi Penelitian Kualitatif, Yogyakarta: Rake Sarasin, hal.171 
deskripsi dan refleksi: Data yang ditulis dalam catatan deskripsi dan refleksi dianalisis secara induktif. Tujuannya untuk menemukan simpul-simpul sementara. Kemudian dikembangkan pertanyaan atau hipotesis baru, selanjutnya mengadakan penelitian lagi untuk memperoleh jawaban dan perluasan data dan seterusnya (prinsip snow-ball). Kedua, analisis setelah di lapangan dilakukan dengan mengkategori, menemukan konsep lokal dan menghubungkan antar konsep, sehingga ditemukan profil budaya masyarakat atau keluarga beda agama setempat.

\section{E. Hasil Penelitian dan Pembahasan}

\section{Keberagamaan dan Penerapan Hukum Kewarisan}

a. Keberagamaan Suami-Isteri

Sesudah perkawinan tingkat keberagamaan suami-isteri dari keluarga beda agama banyak yang tergolong cukup/sedang dan rendah (masing-masing 38\%), walaupun begitu ada seperempat dari mereka yang tergolong tinggi. Sementara sebelum mereka kawin dengan pasangannya masing-masing yang berbeda agama, lebih dari separuh (56\%) dari mereka tergolong tinggi keberagamaannya, dan hanya sedikit yang memiliki keberagamaan rendah.

Kalau dibandingkan tingkat keberagamaan sebelum dan sesudah perkawinan menunjukkan sebagai berikut: setelah perkawinan berlangsung ada kecenderungan keberagamaan suami atau isteri mengalami penurunan tingkat keberagamaannya, dan sebaliknya semakin banyak di antara mereka yang memiliki keberagamaan rendah.

Perubahan tingkat keberagamaan tersebut mayoritas terdapat pada pemeluk Katolik/Kristen, baik dari kalangan suami maupun isteri. Adapun pada penganut Islam hanya terdapat pada isteri. Seperti pada kasus suami Katolik/Kristen, isteri Katolik/ Kristen juga banyak mengalami perubahan tingkat keberagamaan. Mereka yang termasuk kategori tinggi semakin sedikit dan yang termasuk kategori sedang semakin banyak. Sementara pada isteri Islam mereka yang termasuk tinggi juga semakin sedikit dan sebaliknya yang termasuk kategori rendah semakin banyak.

b. Penerapan Hukum Kewarisan

Walaupun hukum kewarisan baru akan berlaku jika orang sudah meninggal dunia, namun jawaban subyek pada saat sekarang terhadap persoalan ini menunjukkan kecenderungan atau sikap yang akan diambil oleh mereka nantinya. Sikap yang diambil oleh mereka tersebut menggambarkan juga sejauhmana dominasi kebudayaan tertentu mempengaruhi mereka.

Mayoritas subyek akan menerapkan hukum kewarisan adat, baik dari kalangan suami-isteri Islam maupun suami-isteri Katolik/Kristen. Pada intinya mereka beralasan hukum adat dianggap lebih sesuai dan patut dihormati. Dengan kata lain, kebudayaan suku, khususnya di bidang kewarisan, lebih dominan dibandingkan dengan kebudayaan agama. 


\section{Perkawinan Beda Agama dan Harmonisasi Keluarga}

a. Faktor-Faktor Terjadinya Perkawinan Beda Agama

Walaupun banyak agama tidak membolehkan umatnya kawin dengan orang yang berbeda agama, namun dalam realitas, khususnya di Sinduadi, masih banyak terjadi perkawinan beda agama. Hal ini terjadi karena beberapa faktor yaitu: (1) terjadinya proses kontraksi dari keluarga luas ke keluarga inti, (2) dominasi subbudaya abangan dalam masyarakat, (3) perubahan prinsip-prinsip dalam pranata perkawinan.

Pertama, perubahan struktur keluarga yang terjadi dalam masyarakat terjadi pula pada keluarga beda agama. Perubahan struktur itu berupa proses kontraksi keluarga yaitu proses perubahan dari keluarga luas menjadi keluarga inti (batih). Proses kontraksi keluarga ini memunculkan otonomi dan liberalisasi keluarga inti yang lebih kuat. Adanya otonomi menunjukkan tingkat kemandirian keluarga inti yang tinggi. Otonomi ini diiringi dengan terjadinya liberalisasi dari (anggota) keluarga inti. Anggota keluarga inti lebih mempunyai kebebasan dalam memutuskan semua hal yang berkaitan dengan persoalan internal keluarga.

Semakin kuatnya otonomi dan munculnya liberalisasi keluarga inti akibat proses kontraksi keluarga dapat menjadi penyebab terjadinya perkawinan beda agama. Sebab dari faktor-faktor tersebut mengindikasikan juga adanya kontrol sosial yang melemah dari kerabat luas terhadap (anggota) keluarga inti. Hal ini pada akhirnya memberikan keleluasaan bagi (anggota) keluarga inti menentukan pasangan perkawinan tanpa terpaku dengan nilai-nilai yang menjadi anutan kerabat luas, terutama nilai-nilai keberagamaan.

Kedua, fenomena perkawinan beda agama ini terutama dapat dilihat dari pandangan keagamaan suami isteri yang berbeda agama. Pada intinya mereka memandang semua agama itu baik dan sekedar sebagai alternatif pilihan. Mereka selalu memadukan nilai-nilai keagamaan dan lokal dengan mengalahkan nilai keagamaar. (sinkritisisme). Pandangan ini pada akhimya melahirkan sikap toleran dan pada gilirannya tidak memberi ruang gerak bagi simbol-simbol keagamaan untuk berperan. Sebaliknya simbol-simbol keagamaan dimanipulasi untuk kepentingan pribadi, sehingga perbedaan agama bukan menjadi penghalang bagi bersatunya individu yang berbeda agama dalam ikatan perkawinan. Kecenderungan ini sekaligus mengandaikan bahwa kebudayaan (agama) tidak selalu menjadi penghalang sebagai pengintegrsi sosial,justru, karena adanya subkebudayaan abangan yang bersifat sinkritik.

Gejala ini lebih mempertegas dan mendukung temuan Hildred Geertz (1985) hampir setengah abad yang lalu, yang dilakukan di Mojokuto, dan teori modernitas seperti dikemukakan Nottingham (1983). Teori modernitas menyatakan bahwa setiap masyarakat moderen cenderung bersifat toleran terhadap agama lain. Sementara Hildred Geertz menemukan bahwa dari tiga aliran agama Jawa yaitu santri, abangan, dan priyayi seperti dikemukakan Clifford Geertz, kategori abangan memperlihatkan ciri-ciri seperti masyarakat modern yaitu adanya toleransi beragama yang tinggi. Sikap toleransi ini 
akhirnya mempengaruhi berkembangnya perkawinan beda agama, karena dalam setiap hubungan sosial antarindividu tidak membeda-bedakan agama yang dipeluk oleh seseorang.

Ketiga, perubahan budaya Jawa, khususnya dalam pranata perkawinan, misalnya prinsip gudel nyusu kebo yang telah berubah menjadi kebo nyusu gudel (orang tua mengikuti kemauan anak). Prinsip ini menunjukkan kemandirian dan kebebasan anak dalam menentukan jodohnya.

\section{b. Harmonisasi Keluarga}

Faktor-faktor penyebabnya terus berlangsungnya keluarga beda agama meliputi (1) dominasi sub budaya abangan, (2) gejala sekularisme, (3) formalisme agama, (4) pola hubungan tenggang rasa, dan (5) faktor anak.

Pertama, sebagaimana diulas sebelumnya bahwa pandangan keagamaan subgolongan abangan yang bersifat sinkritik telah melahirkan sikap dan perilaku toleransi terhadap orang yang berbeda agama. Agama juga hanya menjadi salah satu alternatif 1, ilihan dari sekian pilihan. Simbol-simbol agama yang berbeda bukan menjadi penghalang bagi bersatunya individu yang berbeda agama. Akibatnya bukan saja dapat menumbuhsuburkan perkawinan beda agama, namun lebih jauh menjadikan keluarga beda agama terus mampu memelihara keutuhan rumah- tangganya. Simbol-simbol keagamaan yang berbeda, yang telah termanipulasi, justru menjadi faktor pengintegrasi keberlangsungan keluarga beda agama dan sebaliknya menyebabkan hampir tidak pernah terjadi perceraian di kalangan mereka.

Tidak adanya perceraian di kalangan keluarga beda agama sangat berbeda dengan kecenderungan yang ada di Amerika Serikat seperti dikemukakan beberapa peneliti. Collins (1987) mencatat bahwa perceraian di kalangan keluarga beda agama (religious intermarriage) lebih sering terjadi dibandingkan dengan keluarga yang satu agama. Elliot dan Merrill (dalam Khairuddin, 1997) menjelaskan yang senada yaitu perbedaan agama dalam keluarga menyebabkan seringnya konflik internal, terutama setelah anak lahir. Konflik akan lebih serius lagi jika suami-isteri memiliki ketaatan agama yang tinggi.

Kedua, tesis Elliot dan Merrill yang menyatakan konflik akan lebih tajam jika suami-isteri yang berbeda agama memiliki ketaatan beragama perlu dikritisi. Sebab dalam beberapa kasus ternyata ketaatan agama yamg tinggi belum tentu berpengaruh kepada munculnya konflik diantara suami-isteri tersebut, masih ada faktor lain yang perlu dipertimbangkan yaitu mengenai pandangan keagamaan masyarakat pandangan dan perilaku yang sekularistik dari suami atau isteri, khususnya dalam persoalan hubungan ritual agama (keberagamaan) dengan aspek sosial. Mereka memisahkan antara aspek ritual keagamaan dengan aspek sosial. Akibatnya walaupun tingkat keberagamaan mereka tinggi dan sedang namun tidak mempengaruhi terhadap aspek sosial mereka. 
Ketiga, kalau perilaku sekularisme berusaha mensubordinasi agama dalam menghadapi persoalan sosial, khususnya hubungan sosial antara suami-isteri, maka dalam formalisme agama sebaliknya. Agama dijadikan sumber acuan dalam melakukan tindakan sosial, khususnya dalam memelihara hubungan yang baik dan mencegah konflik rumah tangga, terutama untuk tidak terjadinya perceraian.

Keempat dan kelima, pola hubungan yang didasarkan atas tenggang-rasa di antara suami-isteri. Suatu hubungan yang penuh kasih-sayang dan selalu mencegah dan memperkecil terjadinya perselisihan, sehingga perbedaan sistem sosial budaya-agama tidak menjadi permasalahan. Hal ini terkait dengan kehidupan rumah tangga yang berorientasi kepada kepentingan anak-anak.

\section{Sosialisasi Nilai Agama}

\section{a. Pembinaan Agama Anak}

Bagi orang tua di kalangan masyarakat Jawa, khususnya dari keluarga beda agama, agama bagi anak-anak yang belum dewasa masih dianggap bersifat tentatif atau sementara, karena penganutan agama yang sesungguhnya adalah ketika mereka sudah menginjak dewasa. Batasan kedewasaan ini setidak-tidaknya pada usia SMA. Walaupun begitu kebanyakan anak akan tetap memilih agama yang sudah dianutnya ketika masa tentatif. Ada dua pola pembinaan yang diambil oleh orang tua:

Pertama, kebanyakan orang tua dalam keluarga beda agama kurang bahkan hampir tidak memberikan pembinaan keagamaan secara langsung kepada anak-anaknya misalnya pengajaran do'a harian seperti doa makan, do'a sholat, pembiasaan membaca al-Qur'an dan al-Kitab di rumah ataupun melalui pengadaan suasana rumah yang religius seperti melalui pemberian simbol-simbol keagamaan berupa tulisan, salib atau kaligrafi ayat al-Qur'an. Anak diberikan kebebasan memilih agamanya sendiri.

$K e d u a$, orang tua mengarahkan dan membina agama anaknya. Dalam hal in! ada dua bentuk: (1). Orang tua memberi pengertian tentang agama yang dianut masingmasing suami-isteri, namun anak tidak dipaksa untuk mengikuti agama tertentu, pilihan (akhir) diserahkan kepada anak-anak. Dalam kasus ini kebanyakan orang tua tidak memberikan pembinaan keagamaan secara langsung di rumah, ada juga yang hanya memberikan motivasi untuk memperoleh pengetahuan keagamaan melalui lembaga keagamaan seperti remaja masjid. (2). Orang tua memberi pengertian tentang agama yang dianutnya masing-masing, namun sejakawal anaksudah ditentukan afiliasi agamanya oleh orang tuanya. Hal ini terjadi karena adanya perjanjian antara suami (Islam) dan isteri (Katolik) sebelum mereka mempunyai anak. Anak sejak dini sudah dibina dengan nilai-nilai agama Katolik, baik secara langsung di dalam rumah maupun di luar rumah. Data tersebut menunjukkan bahwa, kebanyakan orang tua kurang atau bahkan hampir tidak memberikan perhatian terhadap pembinaan agama anak-anaknya. Rendahnya pembinaan keagamaan yang dilakukan orang tua berpengaruh terhadap rendahnya kualitas agama anak-anaknya. 
Temuan ini sekaligus menunjukkan bahwa, peranan orang tua ab́angán dari keluarga beda agama dalam hal sosialisasi agama, khususnya pembinaan agama, tidak bersifat primer. Hal ini berbeda dengan peranan yang dimainkan mereka dalam sosialisasi kejawen (budaya Jawa) seperti juga ditemukan Hildred Geertz (1985).

Memang ada anak dari keluarga beda agama yang memiliki kualitas agama yang baik, namun umumnya mereka berasal dari suami atau isteri yang masuk kategori taat dan atau adanya pengaruh kerabat atau lingkungan sosial seperti masjid, sekolah agama dan kelompok pengajian. Kerabat dan atau lingkungan sosial secara sendiri-sendiri atau bersama-sama ikut berperan dalam pembinaan agama anak dari keluarga beda agama. Peranan lingkungan sosial memang tidak dapat dipisahkan dengan prakarsa atau sikap pasif orang tua. Kalau ada prakarsa dan dorongan orang tua, terutama dari orang tua yang santri (tradisional). Lingkungan sosial lebih kuat lagi peran dalam pembinaan anak jika anak berasal dari orang tua agama-penuturan.

\section{b. Proses Afiliasi AgamaAnak}

Ada dua hal yang penting dicatat dalam afiliasi agama anak ini. Pertama, ibu lebih besar perannya dibandingkan dengan ayah dalam afiliasi agama anak. Rasio perbandingan pengaruh paternal dengan maternal hanya mencapai $1: 1,06$. Pengaruh ayah dan ibu terhadap anak laki-laki dan anak perempuan masing-masing $1: 1,25$ dan 1 $: 1$. Hal ini berarti pengaruh maternal lebih kuat daripada pengaruh paternal, terutama terhadap anak laki-laki.

Kedua, kalau dibandingkan pengaruh ibu dan ayah terhadap anaknya yang berbeda jenis kelamin menunjukkan bahwa, anak laki-laki justru cenderung kuat ikut agama ibu, sedangkan untuk anak perempuan tidak selalu ikut agama ayah, anak perempuan sama-sama kuat ikut agama ibu dan ayah, walaupun begitu selisih persentase anak laki-laki masih lebih besar daripada anak perempuan yang berada dibawah anak perempuan yang ikut agama ibu.

Kecenderungan pertama tidak jauh berbeda dengan temuan penelitian di Indonesia maupun di luar Indonesia. Penelitian Aini (1997) di Indonesia menemukan rasioperbandingan pengaruh paternal dan maternal terhadap afiliasi agama anak 1: 1,7. Sedangkan Nelson (1990) di Australia menemukan perbandingan yang lebih besar lagi yaitu $1: 2$.

Kecenderungan pertama ini nampaknya relevan dengan teori peranan sosial budaya. Dalam masyarakat yang masih didominasi budaya patriarki, peranan laki-laki dibedakan, isteri mengurus bidang reproduktif termasuk pengasuhan anak, sedangkan ayah lebih mengurus sektor produktif dan sosial. Hal ini akan berpengaruh terhadap kualitas dan kuantitas dalam mengurus anak-anak, sehingga anak-anaknya dimungkinkan lebih dekat dengan ibu, baik laki-laki maupun anak perempuan. Pada akhirnya anak akan mengikuti perilaku sosial dan nilai budaya yang dianut oleh ibu.

Kecenderungan kedua agak berbeda dengan temuan beberapa penelitian. Nelson menemukan kenyataan bahwa, anak laki-laki cenderung kuat ikut agama ayah, sebaliknya 
anak perempuan cenderung kuat ikut agama ibu. Hal yang sama ditemukan Landis (1949) di Amerika dan Aini. Kecenderungan kedua ini sekaligus memberikan koreksi terhadap teori psikodinamika. Teori ini menyatakan bahwa setiap anak melakukan proses identifikasi diri dalam struktur sosial-budaya yang menjadi daya paksa baginya. Kemudian sejalan dengan berkembangnya kesadaran akan jenis kelamin yang dimilikinya, maka proses identifikasi sifat dirinya didasarkan pada kesadaran kesamaan sekse dengan orang tuanya. Karena itu dalam konteks penganutan agama anak laki-laki akan cenderung kuat ikut agama ayahnya, sebaliknya anak perempuan cenderung kuat ikut agama ibunya. Adapun dalam penelitian ini, meskipun anak mengidentifikasi perilaku sosial-budaya orang tuanya, termasuk dalam penganutan agama, namun identifikasi itu tidak selalu berdasarkan kesamaan sekte antara anak dan orang tuanya. Artinya anak laki-laki tidak selalu cenderung ikut agama ayahnya, namun justru lebih kuat ikut agama ibu.

\section{Aspek Keberagamaan dan Sosial}

Ada dua hal yang penting dicatat dalam melihat hubungan antara aspek sosial (upaya harmonisasi keluarga, penerapan hukum kewarisan dan sosialisasi nilai) dengan keberagamaan suami-isteri yang berbeda agama.

Pertama, walaupun tingkat keberagamaan suami-isteri tinggi dan sedang, di sisi lain mereka tetap harmonis. Fenomena ini bisa terjadi karena berkembangnya sifat sekularistik suami-isteri dalam keluarga beda agama tersebut. Agama hanya dianggap mencakup urusan pribadi antara individu dengan Tuhannya.

$K e d u a$, hal yang sama juga terjadi pada sosialisasi nilai dalam keluarga dan penerapan hukum kewarisan. Pada kedua bidang ini menunjukkan faktor kualitas keberagamaan yang dimiliki suami-isteri tidak berpengaruh pada aktivitas sosialisasi nilai dan penerapan hukum kewarisan. Dalam kedua bidang ini suami-isteri justru lebih banyak dipengaruhi kebudayaan tradisi dibandingkan dengan kebudayaan agama.

\section{F. Penutup}

Hasil penelitian dapat disimpulkan sebagai berikut: Pertama, tingkat keberagamaan suami-isteri cukup banyak yang tinggi, dan cukupan, terutama sebelum mereka kawin, namun tidak mempunyai pengaruh pada aspek sosial seperti disintegrasi dalam keluarga, peran suami-isteri dalam sosialisasi nilai, dan penerapan kewarisan. Tingkat keberagamaan suami-isteri mengalami penurunan setelah perkawinan berlangsung.

Kedua, agama, sebagai sistem budaya, dapat befungsi sebagai pengintegrasi sosial antara suami-isteri yang berbeda agama karena adanya nilai-nilai modernitas dari subbudaya abangan yang bersifat sinkritik dan subbudaya santri yang sekularistik, sehingga berkembang sikap toleran terhadap penganut agama lain.

Ketiga, kebudayaan agama berperan sedikit dalam sosialisasi nilai-nilai dan kewarisan daripada kebudayaan suku justru karena adanya subbudaya abangaan yang bersifat sinkritik dan subbudaya santri yang sekularistik, sehingga berkembang toleransi. 
: Pada dataran praksis pembangunan di bidang keagamaan, pemerintah dan atau lembaga sosial kemasyarakatan perlu memberi perhatian dalam meningkatkan kualitas keberagamaan suami-isteri dari keluarga beda agama, termasuk terhadap anak-anak mereka. Di sisi lain kepada keluarga beda agama tersebut perlu lebih ditingkatkan nilainilai toleransi yang sudah ada, dan sekaligus mengurangi sikap sekularistik dan sinkritik dalam memahami agama. Untuk lingkup keluarga dan masyarakat yang lebih luas, dengan mengambil hikmah dari kondisi keluarga beda agama ini, maka nilai-nilai toleransi dan keberagamaan, yang tinggi yang tidak bersikap sekularistik-sinkritik, harus ditumbuhkembangkan secara simultan, sehingga proses integrasi dalam masyarakat dapat berlangsung terus, tanpa harus membonsai keberagamaan penganut agama. Sebab toleransi terhadap penganut agama lain merupakan bagian dari pengakuan terhadap pluralisme yang dihormati setiap agama dan sekaligus menjadi persyaratan mutlak tumbuhkembangnya masyarakat madani. Hanya dengan pola seperti, maka agama sebagai sistem budaya akan menampilkan sosoknya sebagai pengintegrasi sosial, bukan sebagai pemecah relah.

Dari hasil penelitian ini sebenarnya masih banyak hal yang perlu ditindaklanjuti untuk diteliti, misalnya latar belakang suku, atau fokus penelitian atau juga perluasan subyek dari perbedaan agama ke keluarga yang berbeda agama sekaligus suku. 


\section{DAFTAR PUSTAKA}

Aini, Noryamin, 1997/1998, Afiliasi Agama Anak dari Keluarga Pernikahan Berbeda Agama, Jakarta: IAIN Syarif Hidayatullah.

Alexander, Jeffrey C. \& Steven Seidman (eds.), 1990, Culture and Society, Contemporary Debates, Cambridge: University Press.

Bahr, HM, 1982, "Religious Intermariage and Divorce in Utah and the Mountain States," dalam Journal for the Scientific Study of Religion. Vol. 20.

Beckford, James \& Thomas S. Kuhn, 1991, The Changing Face of Religion, London: Sage.

Berger, Peter dan Luckman, 1990, Tafsir Sosial Atas Kenyataan. Terjemahan Hasan Basari, Jakarta: LP3ES.

Budiman, Arif, 1985, Pembagian Kerja Secara Seksual Sebuah Pembahasan Sosiologis tentang Peran Wanita dalam Masyarakat, Jakarta: Gramedia.

Collins, Randall, 1987, Sociology of Marriage and the Family, Gender Love and Property, Chicago: Nelson-Hall.

Geertz, Clifford, 1989, Abangan, Santri, Priyayi dalam Masyarakat Jawa, Terjemahan Aswab Mahasin, Jakarta: Pustaka Jaya.

Geertz, Hildred, 1985, Keluarga Jawa, Terjemahan Grafiti Pers, Jakarta: Grafiti Pers.

Hariyono, P., 1994, Kultur Cina dan Jawa, Jakarta: Sinar Harapan.

Ibrahim, Anwar, 1996, The Asian Renaissance, Singapore-Kuala Lumpur: Times Books International.

Khairuddin, 1997, Sosiologi Keluarga, Yogyakarta: Liberty.

Muhadjir, Noeng, 1989, Metodologi Penelitian Kualitatif, Yogyakarta: Rake Sarasin.

Nelson, 1990, "Secularazation in Australia Between 1966 and 1985; AResearch Note" dalam Australian and New Zealand Journal of Sociology, vol.23. 
Nottingham, Elizabeth, 1993, Agama dan Masxyarakat, Terjemahan Abdul Muis Naharong, Jakarta: Rajawali.

Robinson, Philip, 1989, Beberapa Perspektif Sosiologi Pendidikan, Jakarta: Rajawali.

Saadah H, Sri. Hartati, 1991, Dampak Perkawinan Campuran terhadap Tatakrama Daerah Bali, Jakarta: Depdiknas.

Sudjangi (peny.), 1992, Kajian Agama dan Masyarakat, Jakarta: Balitbang Depag RI.

Suparlan, Parsudi, 1982, Pengetahuan Budaya, Ilmu-ilmu Sosial dan Pengkajian Masalah-masalah Agama, Jakarta: Proyek Penelitian Keagamaan Balitbang Depag RI.

Tibi, Bassam, 1991, Islam and the Cultural Accomodation of Social Change, Boulder: Westview Press.

Wiludjeng, JHM, 1991, Faktor-faktor yang Mempengaruhi Pelaksanaan Janji Perkawinan Campur di Keuskupan Agung Jakarta, Jakarta: Pusat Penelitian UAJ. 